Original Research Paper

\title{
Analisis Perancangan LTE Home Pada Jaringan 4G LTE Berbasis Open Radio Access Network
}

\author{
Muhamad Shodikin $^{1^{*}}$ \\ ${ }^{\text {I}}$ Program Studi Magister Terapan Teknik Elektro, Politeknik Negeri Jakarta, Jakarta, Indonesia
}

https://doi.org/10.29303/jpmpi.v3i2.596

Sitasi: Shodikin, M. (2021). Analisis Perancangan LTE Home Pada Jaringan 4G LTE Berbasis Open Radio Access Network. Jurnal Pengabdian Magister Pendidikan IPA, 4(1)

Article history

Received: 02 Desember 2020

Revised: 29 Desember 2020

Accepted: 22 Januari 2021

*Corresponding Author: Muhamad Shodikin, Program Studi Magister Terapan Teknik Elektro, Politeknik Negeri Jakarta, Jakarta, Indonesia. Email:

muhamad.shodikin.te19@mhsw.pnj.ac.id

\begin{abstract}
Penelitian tentang LTE berlanjut hingga teknologi generasi kelima secara resmi ditetapkan oleh badan standar. Ketersediaan jaringan transmisi berbasis serat optik mendorong riset untuk mengoptimalkan kecepatan akses pelanggan rumahan sehingga PT Telkomsel meluncurkan layanan LTE Home berbasis modem CPE untuk menghadirkan komunikasi LTE. Dasar dari teknologi LTE Home adalah penguat sinyal menggunakan modem $\mathrm{CPE}$ di rumah pelanggan. Mudah diimplementasikan tetapi memiliki kelemahan yaitu tidak memancarkan sinyalnya sendiri dan membebani pemancar sumber LTE. Penelitian ini mengusulkan teknologi LTE Home berbasis Open Radio Access Network (ORAN) sebagai solusi, dengan memasang pemancar LTE Home di rumah pelanggan dan terkoneksi langsung ke jaringan inti melalui transmisi pita lebar milik sendiri / sewa. Penelitian ini penting dilakukan karena dapat menyelesaikan masalah konektivitas tidak langsung dengan sistem jaringan inti yang terjadi pada LTE Home berbasis modem CPE dan juga membuka peluang penerapan teknologi seperti IoT untuk rumah pintar dan gedung pintar. Metode penelitian ini menganalisis desain LTE Home berbasis ORAN, model pengukuran Key Performance Indicator (KPI) dan integrasinya ke dalam operator seluler. Batasan penelitian adalah eksplorasi teknologi LTE berbasis ORAN yang disimulasikan secara virtual terintegrasi dengan komponen Open Source. Luaran penelitian ini mendeskripsikan desain LTE Home berbasis ORAN, mendeskripsikan hardware dan software berbasis Open Source yang digunakan, menjelaskan desain dan simulasi teknik LTE Home berbasis ORAN, menjelaskan bahwa ORAN merupakan teknologi berbasis Open Source yang murah namun layak.
\end{abstract}

Keywords: LTE home; modem; CPE; ORAN; IoT; Open Source. memenuhi standarisasi organisasi ITU-R. Teknologi LTE Advanced yang dipastikan akan memenuhi persyaratan untuk disebut sebagai teknologi 4G. Jadi penelitian atas berbagai permasalahan baik teknis maupun non teknis terkait tentang teknologi LTE Anvanced ini masih terus berlanjut hingga teknologi pengganti generasi kelima resmi ditetapkan oleh badan standar yang ada. diperkirakan akan menjadi standarisasi telepon seluler secara global yang pertama. LTE yang di tetapkan 3 GPP pada release 8 dan 9 belum 
Permasalahan utama saat awal teknologi LTE ini digelar terletak pada ketersediaan jaringan transmisi yang memadai. Jaringan transmisi adalah bagian penting yang mengintegrasikan ujung ke ujung dari sebuah sistem jaringan seluler yaitu yang menghubungkan antara jaringan akses sisi pelanggan dengan jaringan inti dari sistem tersebut. Namun sejak fiberisasi jalur serat optik digelar secara besar-besaran lambat laun permasalahan jaringan tersebut dapat teratasi sehingga ketersediaan jaringan pita lebar jalur transmisi terjamin tidak hanya di kawasan perkotaan tetapi juga menembus kawasan pedesaan.

Ketersediaan jaringan pita lebar jalur transmisi berbasis serat optik ini mendorong penelitian lebih lanjut untuk mengoptimalkan kecepatan akses di sisi pelanggan rumahan sehingga salah satu operator seluler yaitu PT Telekomunikasi Seluler Indonesia/Telkomsel meluncurkan layanan teknologi LTE Home berbasis modem CPE yang bisa mengantarkan komunikasi pita lebar standar LTE. Pada dasarnya teknologi layanan LTE Home ini bekerja berdasarkan konsep penguat sinyal dari tower pemancar LTE atau dengan kata lain ia merupakan perangkat repeater berupa modem CPE yang dipasang di rumah pelanggan agar dapat terlayani teknologi LTE secara optimal. Teknologi LTE Home ini mudah diterapkan namun ternyata berpotensi ada kelemahan karena tidak memancarkan sinyal sendiri tetapi memancarkan ulang sinyal LTE dari tower pemancar LTE. Perancangan dan implementasi LTE Home dilakukan dengan merancang jaringan berbasis jaringan 4G LTE, kemudian akan dilakukan analisis kinerja sistem rancangan dengan mengukur performansi pelanggan saat menggunakan layanan voice dan data. Analisis dilakukan dengan mengukur parameter performansi berupa nilai parameter Reference Signal Received Power (RSRP) dan nilai Reference Signal received Quality (RSRQ). Hasil yang diperoleh dari perancangan dan implementasi LTE Home bertujuan untuk mengukur dan menganalisis performansi implementasi LTE home pada jaringan 4G LTE agar sesuai dengan nilai key performance indicator (KPI) yang diharapkan yaitu untuk RF KPI nilai $\mathrm{RSRP}>-90 \mathrm{dBm}$ dan nilai RSRQ > $-8 \mathrm{~dB}$ (Ariyanti, 2014).

Untuk mengatasi permasalahan teknologi LTE Home dengan kelemahan karena tidak memancarkan sinyal sendiri, pada penelitian ini diusulkan teknologi LTE Home berbasis Open Radio Access Network (ORAN) yaitu dengan memasang perangkat radio akses pelanggan/pemancar LTE Home di rumah pelanggan yang terkoneksi langsung ke sistem jaringan inti melalui jalur transmisi pita lebar yang ada baik secara sewa maupun menggelar sendiri jaringan jalur transmisi tersebut. Perancangan ini akan dilakukan dan hasilnya akan diukur dengan parameter Key Performance Indicator (KPI) standar LTE sebagaimana pengukuran pada penelitian LTE Home berbasis modem CPE/repeater terdahulu.

Penelitian ini penting untuk dilakukan dan diimplementasikan karena akan bisa mengatasi masalah konektifitas langsung dengan sistem jaringan inti yang terjadi pada teknologi LTE Home berbasis modem CPE dan juga membuka peluang penerapan teknologi yang lain semisal Internet of Things (IoT) untuk aplikasi rumah pintar (smart home) maupun gedung pintar (smart building).

Penelitian ini akan dilakukan melalui dua tahapan besar yaitu yang pertama tahap simulasi dan tes dengan perangkat lokal dengan melakukan percobaan hingga sistem berhasil dan berjalan dengan baik baru kemudian ke tahap kedua uji coba mengintegrasikan dengan salah satu operator seluler.

\section{Metode}

Menuju Konsep Open Radio Access Network (ORAN)

Konsep Open-RAN (O-RAN) berfokus pada dua pilar fundamental: Keterbukaan dan Kecerdasan. Antarmuka terbuka sangat penting untuk mendukung vendor dan operator yang lebih kecil untuk dengan cepat memperkenalkan layanan baru, dan memungkinkan operator untuk menyesuaikan jaringan berdasarkan kebutuhan mereka sendiri. Keterbukaan juga memungkinkan penerapan V-RAN multivendor, menghasilkan ekosistem yang lebih kompetitif dan lebih kaya. Selain itu, desain perangkat lunak dan perangkat keras open source dapat memfasilitasi inovasi dan penerapan komersial yang lebih cepat dan lebih efisien, sambil mempertahankan kompatibilitas ke belakang dengan sistem lama. Sistem nirkabel masa depan seperti 5G dan di luar 5G juga akan menjadi jauh lebih kompleks, karena kepadatan jaringan dan 
aplikasi yang lebih kaya dan lebih menuntut. Oleh karena itu, operator dan vendor jaringan seluler harus mengatur dirinya sendiri. Mereka harus dapat memanfaatkan teknologi baru, seperti Machine Learning (ML) dan Artificial Intelligence (AI), untuk mengotomatiskan fungsi jaringan operasional dan mengurangi biaya operasional. Industri telekomunikasi telah mengidentifikasi upaya untuk menyediakan RAN virtual terbuka sebagai langkah evolusioner penting pertama menuju 5G. Gambar 1 menggambarkan hubungan dan evolusi konsep CRAN dan turunannya V-RAN dan O-RAN.

Jumlah kegiatan penelitian dan pengembangan yang berfokus pada konsep O-RAN terus meningkat di bawah payung aliansi O-RAN yang menyediakan kerangka kerja yang diperlukan untuk pengembangan dan penyebaran komersial ORAN. Inisiatif O-RAN berasal dari tiga prinsip utama:

- Memimpin industri menuju antarmuka yang terbuka dan dapat dioperasikan, virtualisasi RAN, dan kecerdasan RAN yang memungkinkan data besar;

- Menentukan API dan antarmuka, mendorong standar untuk mengadopsi mereka sebagaimana mestinya, dan jelajahi sumber terbuka jika sesuai;

- Memaksimalkan penggunaan perangkat keras umum dan perdagangan silikon dan meminimalkan perangkat keras berpemilik.[10]

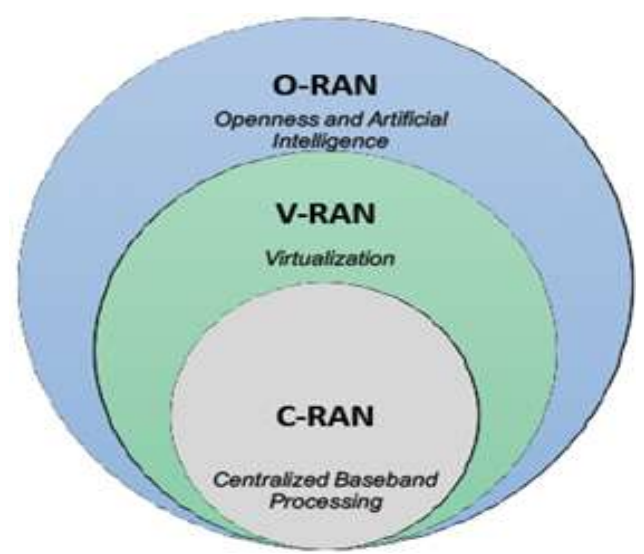

Gambar 1. Evolusi menuju O-RAN

Konsep Jaringan LTE dan LTE Home (CPE WTTX)

Long Term Evolution (LTE) merupakan teknologi berbasis IP yang dikeluarkan oleh 3GPP sebagai standar untuk komunikasi data nirkabel berkecepatan tinggi (Pranoto, 2015). Sistem 4G
LTE telah diperkenalkan sebagai versi terbaru teknologi mobile. 4G didefinisikan untuk memenuhi persyaratan yang ditetapkan oleh International Telecommunication Union (ITU) sebagai bagian dari IMTAdvanced (Ariyani, 2016). Penggerak utama bagi evolusi arsitektur jaringan pada sistem 4G adalah: berbasis all-IP (Internet Protocol), mengurangi biaya jaringan, mengurangi latency data dan signalling, interworking mobility antara jaringan akses lainnya di 3GPP dan non3GPP, always-on bagi user experience dengan kualitas layanan yang mendukung Quality of Services (QoS) dan kemampuan roaming di seluruh dunia (Wulandari, 2017). Arsitektur LTE dikenal dengan suatu istilah System Architecture Evolution (SAE) yang menggambarkan suatu evolusi arsitektur dibandingkan dengan teknologi sebelumnya. Secara keseluruhan LTE mengadopsi teknologi Evolved Packet System (EPS). Didalamnya terdapat tiga komponen penting yaitu UE (User Equipment), E-UTRAN (Evolved UMTS Terrestial Radio Access Network), dan EPC (Evolved Packet Core) (Hikmaturokhman, 2017). Arsitektur jaringan LTE ini dapat dilihat pada Gambar 2.

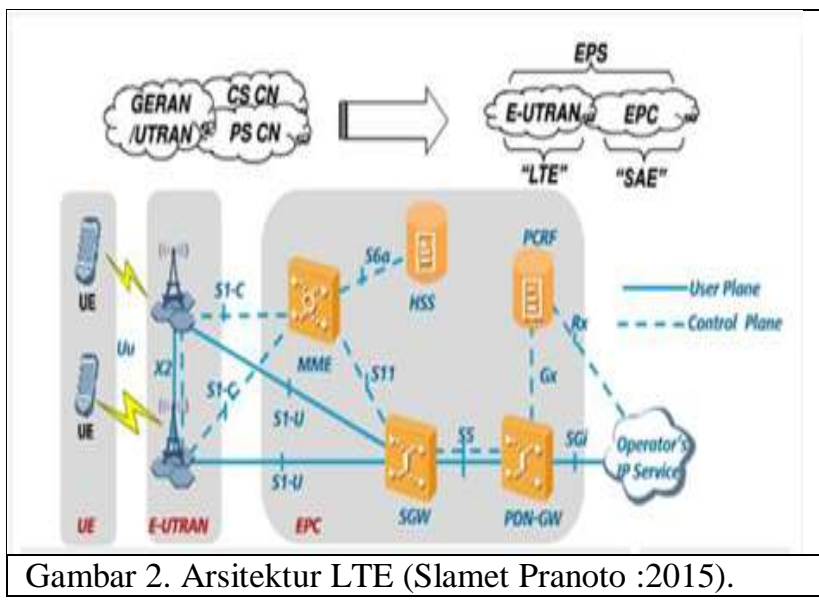

Komponen utama dari arsitektur LTE tersebut diatas adalah:

1. E-UTRAN Evolved UMTS Terresterial Radio Access Network atau E-UTRAN adalah sistem arsitektur LTE yang memiliki fungsi menangani sisi radio akses dari UE ke jaringan core. Berbeda dari teknologi sebelumnya yang memisahkan Node B dan RNC menjadi elemen tersendiri, pada sistem LTE E-UTRAN hanya terdapat satu komponen yakni Evolved Node B 
(eNode B) yang telah emnggabungkan fungsi keduanya. eNode B secara fisik adalah suatu base station yang terletak dipermukaan bumi (BTS Greenfield) atau ditempatkan diatas gedung-gedung (BTS roof top).

2. Evolved Packet Core (EPC) EPC adalah sebuah system yang baru dalam evolusi arsitektur komunikasi seluler, sebuah system dimana pada bagian core network menggunakan all-IP. EPC menyediakan fungsionalitas core mobile yang pada generasi sebelumnya $(2 \mathrm{G}, 3 \mathrm{G})$ memliki dua bagian yang terpisah yaitu Circuit switch (CS) untuk voice dan Packet Switch (PS) untuk data. EPC sangat penting untuk layanan pengiriman IP secara end to end pada LTE. Selain itu, berperan dalam memungkinkan pengenalan model bisnis baru, seperti konten dan penyedia aplikasi. EPC terdiri dari MME (Mobility Management Entity), SGW (Serving Gateway), HSS (Home Subscription Service), PCRF (Policy and Charging Rules Function), dan PDN-GW (Packet Data Network Gateway) (Wulandari, 2019)

Pada 4G LTE penggunaan spektrum frekuensi $2300 \mathrm{MHz}$ diimplementasikan bersama dengan jaringan 4G LTE pada frekuensi $1800 \mathrm{MHz}$ yang sudah berjalan. Metode pemakaian bersama kedua frekuensi tersebut dilakukan dengan metode carrier agregation (Chaerunisa, 2017)

LTE Home merupakan layanan teknologi Wireless Broadband yang berbasis teknologi $4 \mathrm{G}$ LTE, sehingga mempunyai performansi yang jauh lebih baik dibandingkan teknologi akses jaringan fixed [2]. Layanan LTE home merupakan bentuk layanan WBB yang dikenal sebagi teknologi WTTx (Wireless to the X). Teknologi WTTx mempunyai beberapa kelebihan dibandingan dengan teknologi FTTx yang sudah ada, yaitu Liu (2017):

1. Mempunyai kecepatan data yang lebih tinggi bila dibandingan dengan fiber optik (FO)

2. Mampu meningkatkan wilayah jaringan (coverage area)

3. Mempunyai nilai cost yang trendah, sehingga mengurangi waktu dalam pemasaran (Lower Costs: Reduced Time to Market)

4. Pengembangannya lebih flexibel baik untuk wilayah Urban Area maupun Rural Area

5. Menghasilkan Comprehensive Services seperti pada Jaringan kabel (Wired Networks)
Teknologi Passive Optical Network (PON)

Teknologi PON merupakan teknologi ideal untuk menjamin ketersediaan jalur transmisi data telekomunikasi generasi ke-4 dan generasi setelahnya. Pada saat artikel ini ditulis, sudah banyak jaringan serat optik yang dibangun oleh operator seluler itu sendiri maupun perusahaaan penyedia saluran sewa serat optik sehingga untuk menggunakan layanan teknologi ini tidak lagi dianggap mahal/harganya yang kompetitif. Penulis merekomendasikan teknologi GPON.

GPON merupakan salah satu teknologi yang dikembangkan oleh ITU-T dengan rekomendasi ITU-T G.984.1. GPON menggunakan protokol G-PON Encapsulation Method (GEM) untuk efektifitas pengiriman paket Ethernet yang tinggi melewati GPON (C Lin, 2006). Secara umum, sistem GPON dicirikan dengan sistem Optical Line Termination (OLT) dan Optical Network Unit (ONU) atau Optical Network Termination (ONT) dengan distribusi optik pasif Optical Distribution Network (ODN) yang menghubungkan diantaranya. Hubungan antara OLT dan ONT adalah hubungan Point to Multipoint (P2MP) yaitu dari sebuah port di OLT dapat terhubung ke beberapa ONT sekaligus (Zou, 2017).

\section{Metode Perancangan}

Perancangan ini adalah untuk menjawab permasalahan teknologi LTE Home berbasis CPE yaitu masalah konektifitas yang tidak langsung antara perangkat $\mathrm{CPE}$ ke jaringan inti yang melalui pemancar sumber. Sebagaimana disebutkan pada bagian pendahuluan bahwa akan diusulkan rancangan berupa prototipe berupa perangkat keras dan perangkat lunak berbasis Open Source.

1. Diagram Blok Sistem End-to End 


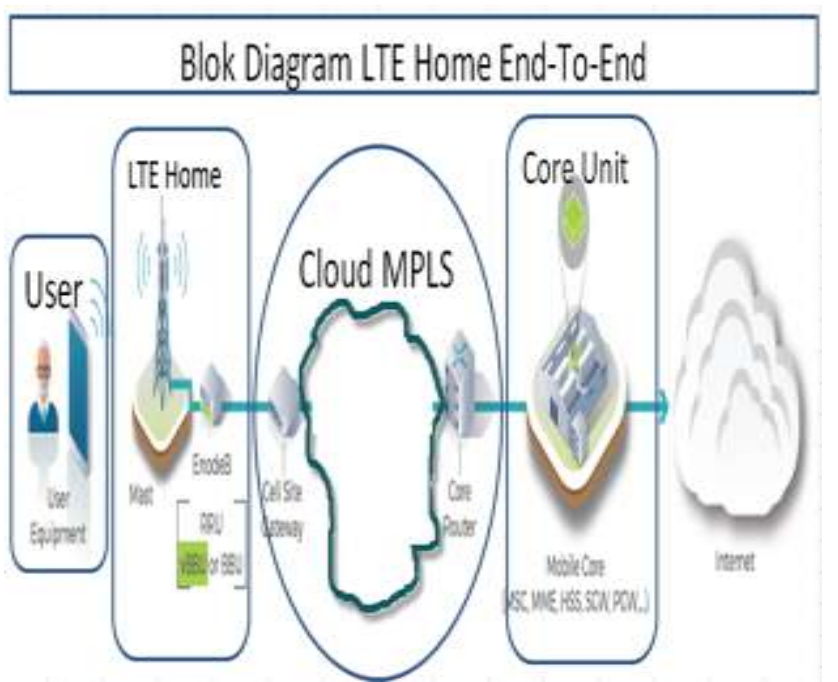

Gambar 3. Arsitektur rancangan LTE Home berbasis O-RAN

Komponen yang membentuk arsitektur jaringan LTE Home berbasis O-RAN end-to-end diuraikan dengan penjelasan sebagai berikut:

a. Blok user: yaitu pengguna jaringan LTE, bisa berupa perangkat bergerak pengguna maupun perangkat IoT yang berguna untuk mengakses jaringan LTE Home.

b. Blok LTE Home: yaitu pemancar LTE yang dipasang di rumah pelanggan dan terkoneksi langsung ke jaringan inti yang berfungsi sebagai jaringan akses bagi blok user/pelanggan.

c. Blok Cloud MPLS: yaitu jalur jaringan transmisi berbasis teknologi MPLS yang berfungsi meneruskan paket data secepat-cepatnya dari pemancar ke jaringan inti dan sebaliknya, konektifitas blok ini dengan seluruh perangkat jaringan direpresentasikan oleh garis jalur biru dari pemancar yang ujungnya keluar menuju jaringan global/internet melalui jaringan inti.

d. Blok Core Unit: yaitu blok jaringan inti yang terdiri dari perangkat standar komunikasi generasi ke-4 yaitu MME, HSS, SGW, PGW yang berfungsi untuk mengatur protokol komunikasi suara dan data.
2. Diagram Blok Prototipe LTE Home

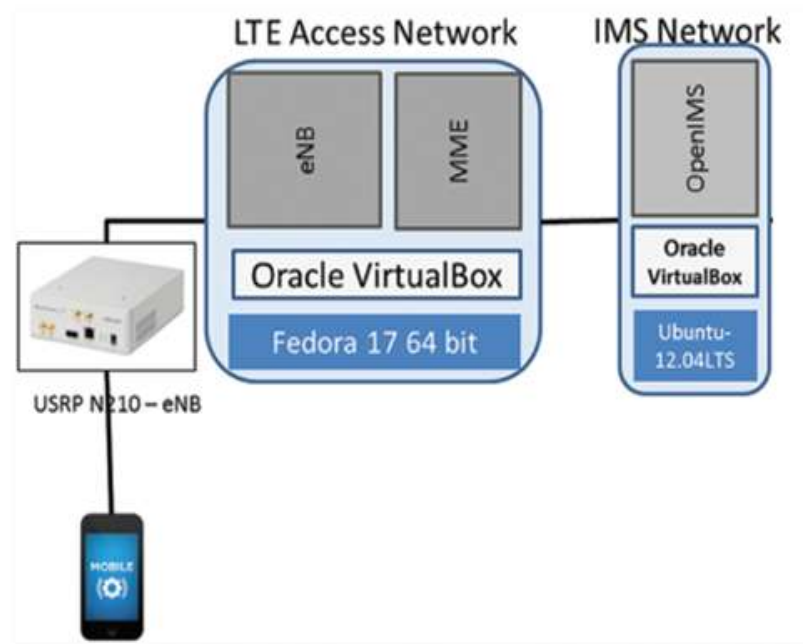

Gambar 4. Rancangan Prototipe Topologi Jaringan LTE Home berbasis ORAN

Perancangan prototipe jaringan LTE Home berbasis O-RAN ini membutuhkan komponen berupa perangkat keras dan lunak. Rincian kebutuhan komponen perangkat keras dijelaskan sebagai berikut:

a. USRP N20-eNB: sebagai radio pemancar sinyal LTE berbasis Software Defined Radio (SDR), bertindak sebagai perangkat keras eNodeB operator seluler yang menyediakan layanan $4 \mathrm{G}$ LTE.

b. Perangkat PC LTE Access Network: sebagai perangkat keras tempat instalasi platform yang digunakan untuk menjalankan perangkat lunak jaringan akses LTE berupa MME dan eNB berbasis Open Source

c. Perangkat PC Core Unit/IMS Network: sebagai perangkat keras untuk instalasi platform yang dipakai untuk menjalankan perangkat lunak Core Unit/IMS Network yaitu OpenIMS.

d. Router MPLS: sebagai perangkat yang melakukan routing transmisi paket data dari jaringan akses LTE Home dan ke jaringan inti/Core Unit atau sebaliknya.

e. Switch: sebagai perangkat agregasi jaringan akses LTE Home maupun jaringan inti/Core Unit.

f. UE/Mobile User: perangkat bergerak pengguna untuk mengakses jaringan LTE Home.

Sedangkan perangkat lunak berbasis Open Source yang dibutuhkan untuk membangun prototipe jaringan LTE Home rinciannya adalah: 
a. Linux Fedora 1764 bit: sebagai host sistem operasi utama untuk instalasi platform Oracle Virtual Box di mana host LTE-ENB dan LTEMME akan diinstal di dalam platform tersebut.

b. Oracle Virtual Box: sebagai platform untuk virtualisasi LTE-NB dan LTE-MME.

c. LTE-ENB: sebagai server perangkat lunak yang terkoneksi secara logika ke perangkat keras USRP N210.

d. LTE-MME: sebagai perangkat lunak yang berjalan di atas platform Oracle Virtual Box dipakai untuk Mobility Management jaringan akses LTE Home.

e. Linux Ubuntu 12.04LTS: sebagai host sistem operasi utama untuk instalasi platform Oracle

Diagram instalasi prototipe LTE Home berbasis CPE vs O-RAN

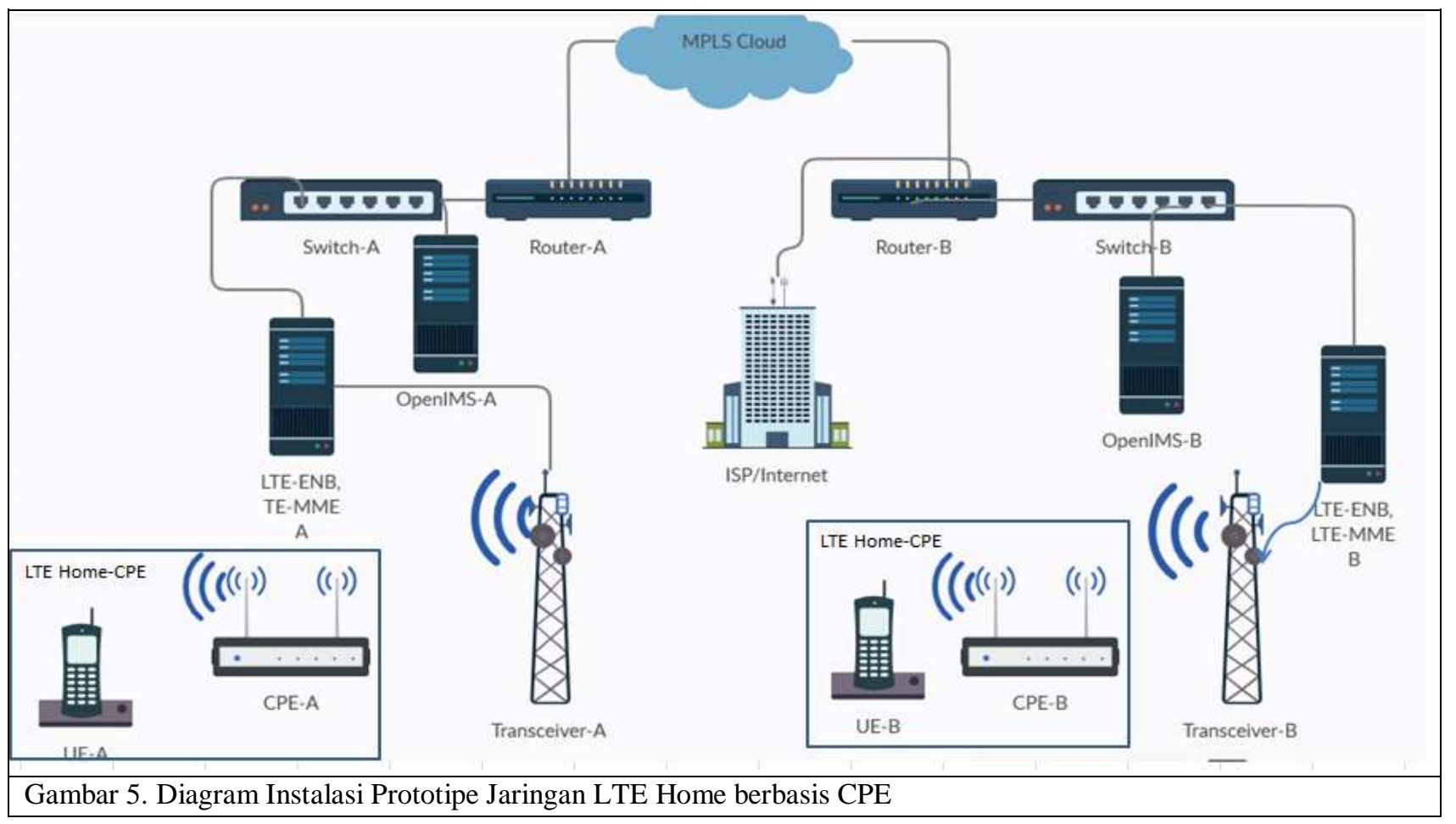

Virtual Box di mana host OpenIMS akan diinstal di platform tersebut.

f. Open IMS: sebagai perangkat lunak yang digunakan untuk membangun Core Unit yang berfungsi sebagai Call Session Control Functions (CSCFs), IMS signaling, Home Subscriber Server (HSS). 


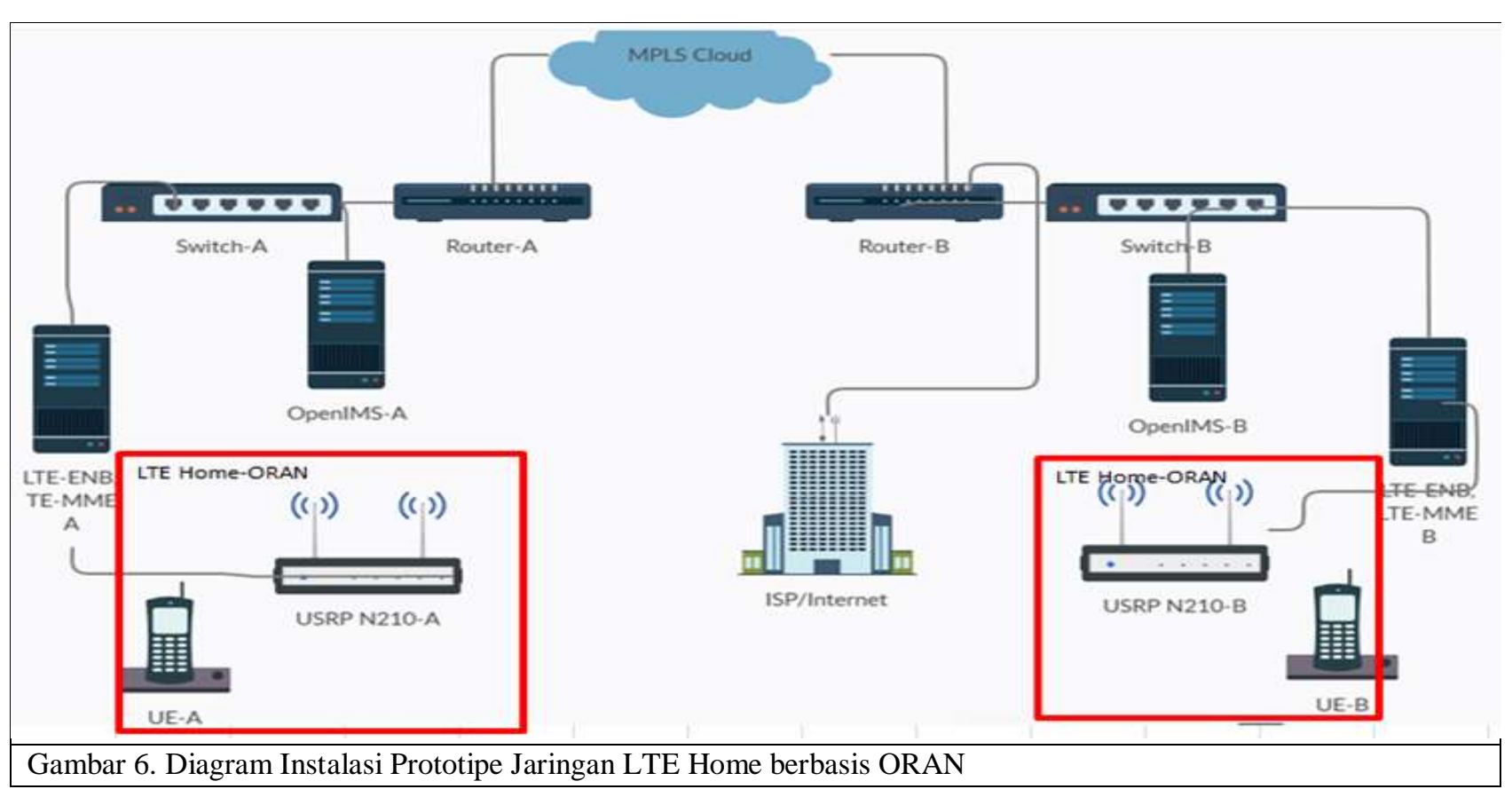

\section{Hasil dan Pembahasan}

Dari hasil analisis perancangan topologi prototipe jaringan LTE Home berbasis O-RAN terdapat beberapa hal yang menjadi perbandingan dengan
LTE Home berbasis CPE yang dapat digambarkan dengan tabel berikut:

Tabel 1. Perbandingan LTE Home berbasis CPE vs O-RAN

\begin{tabular}{|c|l|l|l|}
\hline No & \multicolumn{1}{|c|}{ Basis } & CPE & O-RAN \\
\hline 1 & Antarmuka pemancar & Nirkabel & Serat optik \\
\hline 2 & Sumber sinyal & Menara pemancar LTE & Pemancar sendiri \\
\hline 3 & Konektifitas ke jaringan inti & Tidak langsung & Langsung \\
\hline 4 & Kemungkinan interferensi transmisi & Lebih besar karena nirkabel & $\begin{array}{l}\text { Lebih kecil karena memakai serat } \\
\text { optik }\end{array}$ \\
\hline 5 & Instalasi & Lebih mudah & Mudah \\
\hline 6 & Biaya implementasi & Mahal karena non-Open Source & Murah (Open Source) \\
\hline
\end{tabular}

Berdasarkan perbandingan tabel 1 bagian nomor 1 dengan antarmuka pemancar ke jaringan inti melalui serat optik diharapkan akan menghasilkan kualitas pemancar yang lebih stabil dan memungkinkan kapasitas yang jauh lebih besar dibanding melalui nirkabel.

Dijelaskan sekilas di bagian pendahuluan bahwa LTE Home berbasis O-RAN ini bertujuan memancarkan sinyal LTE langsung ke rumah pelanggan dengan pemancar terpasang di setiap rumah melalui jalur transmisi serat optik sehingga memungkinkan sinyal yang lebih stabil bagi pengguna di dalam rumah dan memungkinkan untuk mendukung stabilitas koneksi IoT rumah pintar. Konektifitas langsung ke jaringan inti mengurangi kemungkinan gangguan jalur transmisi. Penggunaan serat optik sebagai pilihan jalur transmisi diharapkan meminimalkan interferensi yang sering terjadi pada jaringan nirkabel yang bisa mengakibatkan kualitas transmisi data menurun akibat meningkatnya bit error rate (BER). Instalasi yang mudah karena untuk implementasi secara komersial memungkinkan untuk dibuat perangkat pemancar portable yang bisa dipasang di rumah sebagaimana perangkat hotspot Wi-Fi dan berbasis teknologi Open Source yang menjanjikan harga murah karena pengguna bebas mengembangkan sesuai kebutuhan. 
Untuk analisis model pengukuran KPI standar LTE Home berbasis O-RAN terutama nilai parameter Reference Signal Received Power (RSRP) dan nilai Reference Signal received Quality (RSRQ) bisa dilaksanakan saat implementasi prototipe rancangan dengan metode Single Site Verification (SSV) yaitu dengan cara walk test untuk pemancar dalam ruangan dengan perangkat lunak TEMS dan Smartphone untuk pengukuran

\section{Kesimpulan}

Beberapa kesimpulan dari analisis perancangan jaringan LTE Home berbasis O-RAN adalah sebagai berikut:

1. Teknologi LTE Home ini menjanjikan kestabilan dan mampu menjawab permasalahan konektifitas yang ada pada teknologi LTE Home berbasis CPE.

2. Teknologi ini berbasis Open Source sehingga mengatasi masalah inter-operabilitas perangkat antar produsen yang pada akhirnya menjanjikan biaya yang murah namun layak untuk diimplementasikan secara besar-besaran ke seluruh pelosok negeri.

3. Ada beberapa opsi topologi jaringan yang bisa diaplikasikan karena berbasis Open Source.

\section{Daftar Pustaka}

Ariyani, Sovia. "Evaluasi Kualitas Layanan (QoS) Jaringan Data Seluler pada Teknologi 4G LTE". Jurnal Penelitian IPTEKS Juli (2016) : 26-42

Ariyanti, Sri. "Studi Perencanaan Jaringan LTE Area Jabodetabek Studi Kasus PT. Telkomsel". Buletin Pos dan Telekomunikasi Vol 12. No. 4 Desember (2014) : 255-268.

C. Lin. "Broadband Optical Access Network and Fiber- to- the- Home : Systems Technologies and Deployment Strategies". Chicester, England: John Wiley \& Sons, Ltd, 2006.

Chaerunisa, Andi. "Analisa Optimasi Coverage Jaringan LTE TDD pada Frekuensi 2300 $\mathrm{MHz}$ Di Wilayah DKI Jakarta". Proceedings of Seminar Nasional Inovasi dan Aplikasi Teknologi di Industri (2017), ITN, Malang. ISSN 2085-4218 : B8.1 B8.7. kedua parameter tersebut. Berdasarkan hasil rancangan diharapkan hasil KPI memenuhi standar teknologi LTE sebagaimana hasil pada penelitian sebelumnya yaitu LTE Home berbasis CPE.

Pada akhir tahapan penelitian ini adalah integrasi ke operator seluler komersial setelah implementasi dari rancangan prototipe berjalan sesuai yang diharapkan.

4. Teknologi LTE Home ini jika diterapkan dalam skala besar akan bisa mengurangi jumlah tower pemancar yang mengurangi nilai estetika lingkungan.

Saran untuk penelitian lebih lanjut adalah memungkinkan untuk pengembangan 5G Home yang mendukung Machine to Machine Communication (M2M) dengan banyak use case khususnya IoT rumah pintar lanjut.

\section{Ucapan Terima Kasih}

Penulis mengucapkan terima kasih kepada Allah yang telah memberi kekuatan, kesehatan, dan semangat terhadap pengabdian ini.

Gavrilovska, Liljana. "From cloud to Open RAN". Wireless Personal Communications 113(2)(2020). DOI: $10.1007 / \mathrm{s} 11277-020$ 07231-3

Hikmaturokhman, Alfin, and Achmad Rizal Danisya. "4G LTE $1800 \mathrm{MHz}$ Coverage and Capacity Network Planning Using Frekuensi Reuse 1 Model for Rural Area in Indonesia". Proceedings of the 6th International Conference on Software and Computer Applications (2017), ACM.

Huawei. "4G Wireless Broadband Industri White Paper V1.0." ITU Telecom World (2017)

Liu, Gungyi. "WTTx : One way to Monetize the Large Bandwidth." China Mobile (2017)

Pranoto, Slamet. "Pengukuran Performansi Jaringan 4G LTE", Buletin PT. Telekomunikasi Seluler (2015) Oktober 2015, Jakarta 
Recommendation ITU-T G.984.1, Gigabitcapable Passive Optical Networks (GPON): General Characteristics, 2008.

Wulandari, Asri. "Perancangan dan Analisa Implementasi LTE Home Pada Jaringan 4G LTE di Frekuensi 2300 MHz". JST (Jurnal Sains Terapan) 5 (1), 8-15, (2019)

Wulandari, Asri. "Perancangan dan Optimasi Implementasi Small Cell pada Jaringan 4G
LTE di Frekuensi 1800 MHz”. Proceedings of SNTEI Politeknik Negeri Ujung Pandang, November (2017) ISSN 987-602-2-0 : 13-19.

Zou, Youngxi. "The Future Radio Access Technology”. IEEE WCNC (2017), San Fransisco, CA 